\title{
KARAKTERISTIK RUMAH SAKIT DAN KEAKURATAN KODE DIAGNOSIS MEMPENGARUHI HASIL KLAIM INA-CBGs
}

\author{
Warsi Maryatia $\left.{ }^{*}\right)$; Novita Yuliani ${ }^{b}$; Ani Ismayani Justika ${ }^{c}$ \\ a, b, c Program Studi D3 Rekam Medis dan Informasi Kesehatan; Universitas Duta Bangsa Surakarta \\ Jl. K.H. Samanhudi No. 93 Sondakan Laweyan Surakarta
}

\begin{abstract}
Abstrak
Setiap rumah sakit memiliki standar tarif pelayanan kesehatan. Perbedaan tarif rumah sakit dan tarif INA-CBGs serta keakuratan kode diagnosis menyebabkan adanya kesenjangan pendapatan yang diperoleh rumah sakit. Studi ini menilai faktor yang menyebabkan kesenjangan antara tarif rumah sakit dan tarif INA-CBGs, diantaranya karakteristik rumah sakit dan keakuratan kode diagnosis. Sampel diambil secara stratified random sampling sebanyak 100 di dua rumah sakit tahun 2020. Pengumpulan data dilakukan dengan observasi dan kemudian dianalisis dengan uji Chi-Square. Analisis jalur dilakukan dengan pendekatan Structural Equation Modeling (SEM) menggunakan STATA 13 untuk menemukan model yang paling tepat untuk menggambarkan faktor penyebab kesenjangan tarif. Hasil menunjukkan bahwa 34\% kode diagnosis tidak akurat dan $44 \%$ tarif INA-CBGs lebih rendah dari tarif rumah sakit. Rumah sakit milik Pemerintah memiliki log odds 1,037 lebih baik dalam menentukan ketepatan tarif INA-CBGs daripada rumah sakit swasta, namun secara statistik tidak signifikan ( $b=1,037 ; C I 95 \%=-0,115$ hingga 2,189; $p=0,078$ ). Kode diagnosis yang akurat memiliki log odds 3,885 lebih baik dalam menentukan ketepatan tarif INA-CBGs daripada kode diagnosis yang tidak akurat $(b=3,885 ; C 195 \%=2,488$ hingga 5,282; $p<0,001)$.
\end{abstract}

Kata kunci: INA-CBGs, kode, diagnosis, tarif, rumah sakit

\begin{abstract}
Each hospital has a standard health service tariff. Differences in hospital rates and INA-CBG rates as well as the accuracy of the diagnosis code cause a gap in the income earned by the hospital. This study assesses the factors that cause the gap between hospital rates and INA-CBG rates, including hospital characteristics and the accuracy of diagnosis codes. 100 samples were taken by stratified random sampling in two hospitals in 2020. The data was collected by observation and then analyzed by using the Chi-Square test. Path analysis is carried out using the Structural Equation Modeling (SEM) approach using STATA 13 to find the most appropriate model to describe the factors causing the tariff gap. The results show that $34 \%$ of diagnosis codes are inaccurate and $44 \%$ of INA-CBGs rates are lower than hospital rates. Government-owned hospitals had a log odds of 1.037 that were better at determining the accuracy of the INA-CBGs rate than private hospitals, but this was not statistically significant $(b=1.037 ; 95 \% C I=-0.115$ to $2.189 ; p=0.078)$. Accurate diagnostic codes had $\log$ odds of 3.885 better in determining the accuracy of INA-CBGs rates than inaccurate diagnostic codes $(b=3.885$; $95 \% \mathrm{CI}=2.488$ to $5.282 ; \mathrm{p}<0.001)$.
\end{abstract}

Keywords: INA-CBGs, codes, diagnosis, rates, hospitals

\section{Pendahuluan}

Kode diagnosis memiliki peran yang sangat penting penentuan biaya pelayanan kesehatan. Kode diagnosis yang tidak berkualitas akan menyebabkan kerugian bagi rumah sakit baik secara finansial maupun dalam pengambilan

*) Correspondence Author (Warsi Maryati)

E-mail: warsi_maryati@udb.ac.id kebijakan (WHO, 2010). Kode diagnosis sangat membantu dalam perencanaan perawatan pasien di masa yang akan datang, pembuatan rincian tagihan biaya perawatan dan mengurangi risiko manajemen rumah sakit (Hatta, 2013; Cummings dkk, 2011; Dalal \& Roy, 2009; Thigpen dkk, 2015). Klaim biaya pelayanan kesehatan dalam sistem berbasis casemix di negara bagian Victoria, 
Australia bergantung pada kode diagnosis yang tepat, komprehensif dan tepat waktu. Sekitar 16\% dari 752 kasus yang diaudit menunjukkan adanya perubahan Diagnostic Related Groups (DRGs) dan menyebabkan kerugian bagi rumah sakit yang signifikan yaitu AUD 575.300 (Cheng dkk, 2009).

Indonesia dalam pelayanan kesehatannya telah menerapkan sistem casemix dengan Indonesian Case Based Groups (INA-CBGs) pada program Jaminan Kesehatan Nasional (JKN) yang diselenggarakan oleh Badan Penyelenggaran Jaminan Sosial (BPJS). Sistem casemix menggunakan pengelompokan tarif berdasarkan kode diagnosis sesuai International Classification of Diseases and Related Health Problems 10th Revision (ICD-10) (Menteri Kesehatan RI, 2016). Kesalahan dalam menetapakan kode diagnosis pasien dapat menyebabkan perubahan kode INA-CBGs sehingga terdapat perbedaan tarif. Sebagai contoh misalnya, Diabetes mellitus dengan Ulcer of skin dikode dengan E14.9 dan L98.4 menghasilkan kode INA-CBGS E-4-10-II dengan tarif $\mathrm{Rp} 6.617 .568,00$. Kode diagnosis tersebut tidak akurat karena Diabetes mellitus dengan komplikasi Ulcer of skin dapat dikode kombinasi dengan kode E14.5 sehingga menghasilkan kode INA-CBGs I-4-15-I dengan tarif Rp 7.575.541,00. Pada satu kasus tersebut maka rumah sakit rugi sebesar Rp 957.973,00.

Penelitian sebelumnya menunjukkan bahwa kode diagnosis di rumah sakit umum secara signifikan lebih tepat dibandingkan dengan rumah sakit khusus tetapi jumlah kode diagnosis dengan tipe kesalahan besar di rumah sakit umum lebih banyak (Farzandipour dkk, 2010). Dengan demikian, setiap rumah sakit dengan karakteristik berbeda, memiliki tingkat keakuratan kode diagnosis yang berbeda juga. Selain keakuratan kode diagnosis, perbedaan karakteristik rumah sakit seperti kelas, jenis dan kepemilikan rumah sakit menimbulkan perbedaan penetapan tarif pelayanan kesehatan. Hasil studi pendahuluan menunjukkan rumah sakit khusus, rumah sakit swasta dan rumah sakit dengan kelas yang lebih tinggi cenderung memiliki tarif pelayanan kesehatan yang lebih tinggi. Perbedaan tarif antar rumah sakit menyebabkan adanya kesenjangan dimana ada rumah sakit yang diuntungkan dan dirugikan dengan adanya kebijakan tarif INA-CBGs.

Kota Surakarta terdapat rumah sakit dengan karakteristik beragam (Menteri Kesehatan RI, 2019) dan berdasarkan survei pendahuluan rata-rata persentase ketidakakuratan kode diagnosis sebanyak 35\%. Persentase ketidaktepatan kode diagnosis tersebut lebih tinggi dibandingkan rata-rata rumah sakit dalam negeri lainnya yaitu 31,5\% (Rohman dkk, 2011; Sudra \& Pujihastuti, 2016; Arifiamto dkk, 2011; Rahayu dkk, 2011; Abiyasa dkk, 2012; Sarwastutik, 2013; Pujihastuti \& Sudra, 2014; Seruni \& Sugiarsi, 2005; Karimah dkk, 2016; Astuti dkk, 2007) dan masih sangat jauh lebih tinggi dibandingkan dengan rumah sakit di luar negeri yaitu 12,71\% (Cummings dkk, 2011; Dalal \& Roy, 2009; Thigpen dkk, 2015; Cheng dkk, 2009; Farzandipour dkk, 2010).

Penelitian tentang klaim INA-CBGs sudah pernah dilakukan oleh peneliti lain sebelumnya, namun hanya menganalisis secara kualitatif perbedaan besar tarif klaim berdasarkan kode diagnosis. Peneliti juga pernah melakukan penelitian sejenis dengan hasil ada hubungan antara keakuratan kode diagnosis dengan ketepatan klaim asuransi JKN (Maryati, 2017), tetapi penelitian tersebut hanya menganalisis secara bivariat tanpa melihat faktor lain seperti karakteristik rumah sakit. Penelitian ini bertujuan untuk menganalisis faktor yang mempengaruhi kesenjangan antara tarif operasional rumah sakit dengan tarif klaim INA-CBGs yang meliputi karakteriktik rumah sakit dan keakuratan kode diagnosis.

\section{Metode}

Jenis penelitian ini adalah penelitian kuantitatif dengan analisis data sekunder dan desain studi cross sectional. Populasi dalam penelitian ini adalah dokumen rekam medis pasien rawat inap pada tahun 2020. Pada penelitian ini telah ditentukan dua rumah sakit sebagai tempat penelitian dengan pertimbangan karakteristik rumah sakit yang berbeda. Sampel yang akan diambil harus memenuhi kriteria inklusi yaitu: 1) Dokumen rekam medis pasien rawat inap BPJS tahun 2020, 2) Dokumen rekam medis yang memiliki informasi medis secara lengkap, 3) Dokumen rekam medis yang tidak sedang digunakan dalam masa perawatan. Sampel yang dibutuhkan dalam penelitian multivariat sebanyak 15 sampai 20 per variabel (Murti, 2015). Penelitian ini memiliki 5 variabel sehingga sampel yang dibutuhkan adalah $5 \times$ (15 s.d. 20) yaitu 75 sampai 100, maka peneliti menggunakan 100 dokumen. Sampel dipilih secara stratified random sampling dengan 50 dokumen untuk setiap rumah sakit. Variabel dalam penelitian ini dapat dilihat pada Tabel 2.1 berikut : 
Tabel 1 Variabel

\begin{tabular}{|c|c|c|}
\hline No & Variabel & Definisi \\
\hline 1 & $\begin{array}{l}\text { Keakuratan } \\
\text { kode } \\
\text { diagnosis }\end{array}$ & $\begin{array}{c}\text { Kode diagnosis dalam satu } \\
\text { episode perawatan pasien } \\
\text { berdasarkan ICD-10 } \\
\text { Skala data: Kategorikal } \\
\text { Dikategorikan menajdi: } \\
\text { Akurat }=0 \\
\text { Tidak Akurat }=1\end{array}$ \\
\hline 2 & $\begin{array}{l}\text { Kelas Rumah } \\
\text { Sakit }\end{array}$ & $\begin{array}{c}\text { Pengelompokan rumah } \\
\text { sakit berdasarkan fasilitas } \\
\text { dan kemampuan pelayanan } \\
\text { Skala data: Kategorikal } \\
\text { Dikategorikan menjadi: } \\
\text { A }=0 \\
\text { B }=1\end{array}$ \\
\hline 3 & $\begin{array}{l}\text { Jenis Rumah } \\
\text { Sakit }\end{array}$ & $\begin{array}{c}\text { Pengelompokan rumah } \\
\text { sakit berdasarkan cakupan } \\
\text { bidang pelayanan dan jenis } \\
\text { penyakit yang dilayani } \\
\text { Skala data: Kategorikal } \\
\text { Dikategorikan menjadi : } \\
\text { Khusus }=0 \\
\text { Umum }=1\end{array}$ \\
\hline 4 & $\begin{array}{l}\text { Kepemilikan } \\
\text { Rumah Sakit }\end{array}$ & $\begin{array}{c}\text { Pengelompokan rumah } \\
\text { sakit berdasarkan badan } \\
\text { penyelenggara } \\
\text { Skala data: Kategorikal } \\
\text { Dikategorikan menajdi : } \\
\text { Pemerintah }=0 \\
\text { Swasta }=1\end{array}$ \\
\hline 5 & $\begin{array}{c}\text { Tarif } \\
\text { INA-CBGs }\end{array}$ & $\begin{array}{l}\text { Tarif INA-CBGs merupakan } \\
\text { tarif paket berdasarkan } \\
\text { pengelompokan diagnosis } \\
\text { Skala data: Kontinu, } \\
\text { Dikategorikan menjadi : } \\
\text { Tepat }=0 \\
\text { Tidak tepat }=1\end{array}$ \\
\hline
\end{tabular}

Pengumpulan data keakuratan kode diagnosis diperoleh dengan cara membandingkan kode diagnosis yang terdapat pada dokumen rekam medis dengan data kode diagnosis yang terdapat pada INA-CBGs berdasarkan ICD-10. Data kelas, jenis dan kepemilikan rumah sakit diperoleh dari Profil Rumah Sakit, sedangkan data tarif INA-CBGs diperoleh dari membandingkan antara tarif rumah sakit dengan tarif hasil grouper INA-CBGs. Data yang diperoleh ditulis pada lembar checklist untuk direkapitulasi kemudian dianalisis.
Analisis data dimulai dengan analisis univariat untuk mengetahui distribusi frekuensi setiap variabel, kemudian dilanjutkan analisis bivariat menggunakan uji Chi-Square dan analisis multivariat menggunakan uji Regresi Logistik Ganda, sedangkan untuk mengetahui model yang paling tepat dalam menggambarkan hubungan keseluruhan variabel dianalisis dengan analisis jalur. Analisis jalur dilakukan dengan pendekatan Structural Equation Modeling (SEM) menggunakan STATA 13 sesuai langkah berikut ; 1) Spesifikasi Model yang meliputi : a) variabel eksogen (kelas, jenis dan kepemilikan rumah sakit), dan b) variabel endogen (ketepatan kode diagnosis dan tarif INA-CBGs), 2) Identifikasi Model dengan menghitung degree of freedom (df), 3) Kesesuaian Model dan Estimasi Parameter yang ditunjukan oleh koefisien regresi (b), 4) Respesifikasi model yaitu jika model yang dibuat peneliti tidak sesuai dengan model saturasi, koefisien regresi bernilai sangat kecil dan secara statistik tidak signifikan (Murti, 2015). Tahapan penelitian ini dapat dilihat pada Gambar 1 berikut ini :

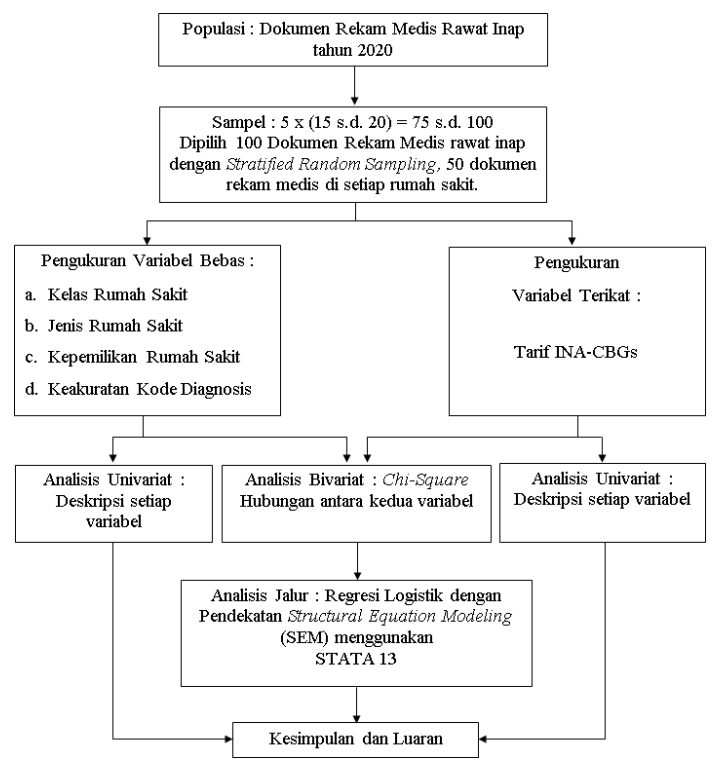

Gambar 1 Tahapan Kegiatan

\section{Hasil dan Pembahasan}

a. Gambaran Umum Rumah Sakit

Penelitian ini menggunakan dua rumah sakit besar di wilayah Surakarta dengan karakteristik yang berbeda-beda. Berikut ini adalah gambaran karakteristik lima rumah sakit tersebut: 
Tabel 2 Karakteristik Rumah Sakit

\begin{tabular}{|c|c|c|c|c|}
\hline No & $\begin{array}{c}\text { Nama } \\
\text { Rumah } \\
\text { Sakit }\end{array}$ & Kelas & Jenis & Kepemilikan \\
\hline 1 & $\begin{array}{l}\text { Rumah } \\
\text { Sakit A }\end{array}$ & B & Umum & Swasta \\
\hline 2 & $\begin{array}{l}\text { Rumah } \\
\text { Sakit B }\end{array}$ & A & Khusus & Pemerintah \\
\hline
\end{tabular}

Berdasarkan table 2 di atas dapat diketahui bahwa dari dua rumah sakit yang diteliti memiliki karakteristik kelas, jenis dan kepemilikan yang berbeda. Rumah saki A merupakan rumah sakit kelas $B$, jenis rumah sakit umum dan milik non Pemerintah (swasta), sedangkan rumah sakit B merupakan rumah sakit kelas $\mathrm{A}$, jenis rumah sakit khusus dan milik Pemerintah.

b. Keakuratan Kode Diagnosis dan Ketepatan Tarif INA-CBGs

Tabel 3 Keakuratan Kode Diagnosis dan Ketepatan Tarif INA-CBGs

\begin{tabular}{ccccc}
\hline \multirow{2}{*}{ Variabel } & \multicolumn{2}{c}{ Tepat } & \multicolumn{2}{c}{ Tidak Tepat } \\
\cline { 2 - 5 } & Jumlah & $\%$ & Jumlah & $\%$ \\
\hline $\begin{array}{c}\text { Kode } \\
\text { Diagnosis } \\
\text { Tarif } \\
\text { INA-CBGs }\end{array}$ & 66 & $66 \%$ & 34 & $34 \%$ \\
\hline
\end{tabular}

Jumlah dokumen rekam medis rawat inap yang diteliti sebanyak 100 dokumen. Sebagian besar kode diagnosisnya sudah akurat yaitu sebanyak $66 \%$ sedangkan kode diagnosis yang tidak akurat sebanyak 34\%. Tarif INA-CBGs hasil grouping yang tepat sebanyak $56 \%$ sedangkan sisanya $44 \%$ dalam kategori tidak tepat (Tabel 3).

c. Hubungan antara Karakteristik Rumah Sakit dan Ketepatan Kode Diagnosis dengan Ketepatan Tarif INA-CBGs

Hasil analisis bivariat menunjukkan bahwa kode diagnosis memiliki hubungan yang signifikan dengan tarif INA-CBGs. Kode diagnosis yang tepat dapat meningkatkan ketepatan tarif INA-CBGs sebesar 42,128 kali lebih baik dibandingkan dengan kode diagnosis yang tidak tepat $(\mathrm{b}=42,128 ; 95 \% \mathrm{CI}$ = 11,127 hingga 159,497; $\mathrm{p}<0,001)$.

Rumah sakit khusus, kelas A dan milik Pemerintah memiliki ketepatan tarif INA-CBGs 1,926 kali lebih baik dibandingkan dengan rumah sakit umum, kelas B dan milik swasta meskipun secara statistik hubungannya tidak signifikan $(b=1,926$; 95\% CI = 0,865 hingga 4,290; $\mathrm{p}=0,158)$.

Penelitian sebelumnya menunjukkan bahwa kode diagnosis di rumah sakit umum secara signifikan lebih tepat dibandingkan dengan rumah sakit khusus tetapi jumlah kode diagnosis dengan tipe kesalahan besar di rumah sakit umum lebih banyak (Farzandipour dkk, 2010).

Tabel 4 Hubungan antara Karakteristik Rumah Sakit dan Kode Diagnosis dengan Tarif INA-CBGs

\begin{tabular}{|c|c|c|c|c|c|c|}
\hline \multirow{2}{*}{ Variabel Bebas } & \multicolumn{2}{|c|}{$\begin{array}{l}\text { Variabel Terikat: } \\
\text { Tarif INA-CBGs }\end{array}$} & \multirow{2}{*}{ OR } & \multicolumn{2}{|c|}{ CI $(95 \%)$} & \multirow[b]{2}{*}{$p$} \\
\hline & Tepat (\%) & $\begin{array}{c}\text { Tidak Tepat } \\
(\%)\end{array}$ & & $\begin{array}{c}\text { Batas } \\
\text { Bawah }\end{array}$ & $\begin{array}{l}\text { Batas } \\
\text { Atas }\end{array}$ & \\
\hline \multicolumn{7}{|l|}{ Kode Diagnosis } \\
\hline Tepat (\%) & $53(80,3 \%)$ & $13(19,7 \%)$ & \multirow{2}{*}{42,128} & \multirow{2}{*}{11,127} & \multirow{2}{*}{159,497} & \multirow{2}{*}{$<0.001$} \\
\hline Tidak Tepat (\%) & $3(8,8 \%)$ & $31(91,2 \%)$ & & & & \\
\hline \multicolumn{7}{|l|}{ Kelas Rumah Sakit } \\
\hline $\mathrm{A}(\%)$ & $32(64 \%)$ & $18(36 \%)$ & \multirow{2}{*}{1,926} & \multirow{2}{*}{0,865} & \multirow{2}{*}{4,290} & \multirow{2}{*}{0,158} \\
\hline $\mathrm{B}(\%)$ & $24(48 \%)$ & $26(52 \%)$ & & & & \\
\hline \multicolumn{7}{|l|}{ Jenis Rumah Sakit } \\
\hline Khusus (\%) & $32(64 \%)$ & $18(36 \%)$ & \multirow{2}{*}{1,926} & \multirow{2}{*}{0,865} & \multirow{2}{*}{4,290} & \multirow{2}{*}{0,158} \\
\hline Umum (\%) & $24(48 \%)$ & $26(52 \%)$ & & & & \\
\hline \multicolumn{7}{|c|}{ Kepemilikan Rumah Sakit } \\
\hline Pemerintah (\%) & $32(64 \%)$ & $18(36 \%)$ & \multirow{2}{*}{1,926} & \multirow{2}{*}{0,865} & \multirow{2}{*}{4,290} & \multirow{2}{*}{0,158} \\
\hline Swasta (\%) & $24(48 \%)$ & $26(52 \%)$ & & & & \\
\hline
\end{tabular}


d. Hasil Analisis Jalur

1) Spesifikasi Model

Uji spesifikasi model menggambarkan hubungan antara variabel-varibel yang diteliti. Pada penelitian ini terdapat 5 variabel yang terukur (observed variable) yaitu kelas RS, jenis RS, kepemilikan RS, keakuratan kode diagnosis dan ketepatan tarif INA-CBGs.

2) Identifikasi Model

Identifikasi model dilakukan dengan mengidentifikasi terlebih dahulu jumlah variabel yang terukur, jumlah variabel endogen, variabel eksogen dan parameter yang akan diestimasi, kemudian dihitung degree of freedom (df) yang menunjukkan analisis jalur dapat dilakukan atau tidak. Model yang akan diuji sesuai Gambar 2 berikut.

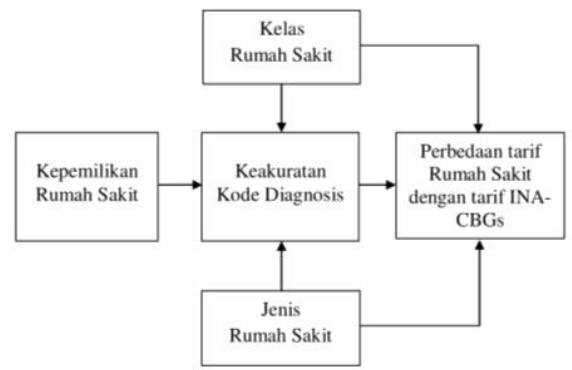

Gambar 2 Model Yang Dianalisis Jalur

a) Jumlah variabel terukur :5

b) Variabel endogen : :2

c) Variabel eksogen :3

d) Jumlah parameter $\quad: 6$ berikut :

Rumus degree of freedom sebagai $\mathrm{df}=$ (jumlah variabel terukur $\times$ (jumlah variabel terukur + 1) / 2 (variabel endogen + variabel eksogen + jumlah parameter)

$=(5 \times(5+1) / 2-(2+3+6)$

$=(30 / 2)-11$

$=15-11$

$=4$

Analisis jalur bisa dilakukan apabila df $\geq 0$, sedangkan pada model analisis jalur ini didapatkan nilai df adalah 4 dan disebut analisis jalur over identified yang berarti analisis jalur ini dapat dilakukan.

3) Kesesuaian Model dan Estimasi Parameter

Berdasarkan hasil analisis jalur dengan menggunakan STATA, diperoleh model yang paling fit menggambarkan hubungan antar variabel adalah sebagai berikut:

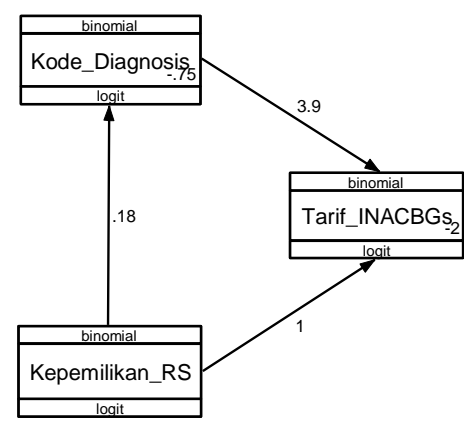

Gambar 3 Spesifikasi Model Hasil Analisis Jalur

Tabel 5 Hasil Analisis Jalur

\begin{tabular}{|c|c|c|c|c|c|c|}
\hline \multirow{2}{*}{$\begin{array}{c}\text { Variabel } \\
\text { Dependen }\end{array}$} & \multirow[t]{2}{*}{ Variabel Independen } & \multirow[t]{2}{*}{$\begin{array}{l}\text { Koefisien } \\
\text { Jalur } \\
\text { (b) }\end{array}$} & \multirow[t]{2}{*}{$\begin{array}{l}\text { Standard } \\
\text { Error }\end{array}$} & \multicolumn{2}{|c|}{ CI $(95 \%)$} & \multirow[t]{2}{*}{$p$} \\
\hline & & & & $\begin{array}{c}\text { Batas } \\
\text { Bawah }\end{array}$ & $\begin{array}{l}\text { Batas } \\
\text { Atas }\end{array}$ & \\
\hline \multicolumn{7}{|l|}{ Direct Effect } \\
\hline \multirow[t]{2}{*}{ Tarif INA-CBGs } & $\begin{array}{l}\text { Kepemilikan RS } \\
\text { Milik Pemerintah }\end{array}$ & 1,037 & 0,588 & $-0,115$ & 2,189 & 0,078 \\
\hline & $\begin{array}{l}\text { Kode Diagnosis } \\
\text { Akurat }\end{array}$ & 3,885 & 0,713 & 2,488 & 5,282 & $<0,001$ \\
\hline \multicolumn{7}{|l|}{ Indirect Effect } \\
\hline Kode Diagnosis & $\begin{array}{l}\text { Kepemilikan RS } \\
\text { Milik Pemerintah }\end{array}$ & 0,178 & 0,423 & $-0,650$ & 1,007 & 0,673 \\
\hline N Observasi & 100 & & & & & \\
\hline Log likelihood & -105.24066 & & & & & \\
\hline df & 5 & & & & & \\
\hline $\mathrm{AIC}$ & 220.4813 & & & & & \\
\hline $\mathrm{BIC}$ & 233.5072 & & & & & \\
\hline
\end{tabular}


Tabel 5 menunjukkan hasil analisis jalur dengan pemilihan Generalized Structural Equetion Modeling (GSEM) pada STATA 13 dengan rincian sebagai berikut:

1. Hubungan Langsung

a. Rumah sakit milik Pemerintah memiliki log odds 1,037 lebih baik dalam menentukan ketepatan tarif INA-CBGs daripada rumah sakit swasta, namun secara statistik tidak signifikan $(b=1,037$; CI95\%= $-0,115$ hingga 2,$189 ; p=0,078)$

b. Kode diagnosis yang akurat memiliki log odds 3,885 lebih baik dalam menentukan ketepatan tarif INA-CBGs daripada kode diagnosis yang tidak akurat $(b=3,885 ; \quad C 195 \%=2,488$ hingga $5,282 ; \mathrm{p}<0,001)$

2. Hubungan Tidak Langsung

Rumah sakit milik Pemerintah memiliki log odds 0,178 lebih baik dalam menentukan kode diagnosis daripada rumah sakit swasta namun secara statistik tidak signifikan $(b=0,178 ; C 195 \%=-0,650$ hingga 1,$007 ;$ $\mathrm{p}=0,673$ )

Perbedaan karakteristik rumah sakit seperti kepemilikan rumah sakit menyebabkan perbedaan dalam penetapan tarif pelayanan kesehatan. Rumah sakit swasta cenderung memiliki tarif pelayanan kesehatan yang lebih tinggi.

Berdasarkan analisis keakuratan kode diagnosis pada rekam medis pasien didapatkan sebanyak 34 (34\%) kode diagnosis yang tidak akurat. Ketidakakuratan kode diagnosis tersebut disebabkan karena informasi medis yang kurang lengkap terutama hasil pemeriksaan penunjang.

Kelengkapan penulisan informasi medis pada setiap formulir rekam medis juga memiliki peran penting dalam menentukan kode yang benar melalui diagnosa yang ditetapkan oleh dokter. Diagnosis tanpa hasil investigasi lengkap dapat menyebabkan kode diagnosis tidak diklaim, yang dapat memengaruhi tingkat keparahan diagnosis (Rohman, 2011). Salah satu cara untuk mendapatkan kode yang akurat adalah dengan memperhatikan informasi pendukung atau penyebab lain yang mempengaruhi kode diagnosis (Astuti dkk, 2007).
Penelitian sebelumnya juga menyatakan bahwa terdapat hubungan yang signifikan antara kelengkapan informasi dalam dokumen rekam medis dengan keakuratan kode diagnosis penyakit pada dokumen rekam medis rawat inap $(\mathrm{p}=$ 0,000) (Pujihastuti dan Sudra, 2014).

Selain kelengkapan informasi medis, penggunaan aturan morbiditas juga mendukung keakuratan kode diagnosis. Hasil penelitian ini menunjukkan bahwa beberapa ketidaktepatan kode diagnosis disebabkan oleh kesalahan penentuan kode diagnostik utama. Ketidakakuratan ini dipengaruhi oleh beberapa faktor antara lain penulisan diagnosis yang tidak jelas dan tidak spesifik sehingga salah dalam menentukan diagnosis utama (Ningtyas dkk, 2019; Iman \& Barsasella, 2018; Maryati, 2016; Opitasari \& Nurwahyuni, 2018; Widyaningrum, 2015).

Dalam rangka menghasilkan kode diagnosis yang akurat, coder sebaiknya memiliki kompetensi pendidikan yang sesuai, keterampilan mengkode yang baik dan penglaman yang cukup. Tanpa adanya dukungan dari faktor coder, diagnosis tidak dapat dikode dengan akurat.

\section{Simpulan dan Saran}

Kode diagnosis secara signifikan berhubungan dengan tarif INA-CBGs. Semakin akurat kode diagnosis maka semakin tepat tarif INA-CBGs. Ketepatan tarif INA-CBGs dapat menentukan jumlah pendapatan yang diterima oleh rumah sakit. Rumah sakit milik Pemerintah memiliki ketepatan tarif INA-CBGs yang lebih baik daripada rumah sakit milik swasta. Ketidakakuratan kode diagnosis disebabkan karena informasi medis yang tidak ditulis dengan lengkap dan hasil pemeriksaan penunjang yang tidak disertakan dalam rekam medis. Pendidikan, keterampilan dan pengalaman coder juga menjadi bagian yang tidak terpisahkan dari faktor pendukung keakuratan kode diagnosis.

\section{Ucapan Terima Kasih}

Terima kasih disampaikan kepada Kementerian Riset dan Teknologi / Badan Riset dan Inovasi Nasional Republik Indonesia yang telah mendanai serta mendukung penelitian ini sampai selesai. 


\section{Daftar Pustaka}

Abiyasa, M.T.; Ernawati, D.; dan Kresnowati, L. 2012. Hubungan antara Spesifitas Penulisan Diagnosis terhadap Akurasi Kode Pada RM 1 Dokumen Rawat Inap Rumah Sakit Bhayangkara Semarang. Jurnal Visi Kesehatan, vol.11, no. 2, pp. 99-104, 2012.

Arifianto, E.; Kresnowati, L.; Ernawati, D. 2011. Keakuratan Kode Diagnosa Utama Dokumen Rekam Medis Pada Kasus Partus Dengan Sectio Cesarean di Rumah Sakit Panti Wilasa Citarum. Jurnal Visi Kesehatan, vol. 10, no. 2, pp. 84-88.

Astuti, R.D; Riyoko; Lena, D. 2007. Tinjauan Akurasi Kode Diagnosis Utama Pasien Rawat Inap Berdasarkan ICD-10 Bangsal Dahlia di RSUD Sukoharjo Triwulan IV Tahun 2007. Jurnal Rekam Medis, vol. 2, no. 1, pp. 25-30.

Cheng, P.; Gilchrist, A.; Robinson, K.M.; Paul, L. 2009. The Risk and Consequences of Clinical Miscoding due to Inadequate Medical Documentation: A Case Study of the Impact on Health Services Funding. Health Information Management Journal, vol. 38, no. 1, pp. 35-46.

Cummings, E.; Maher, R.; Showell, C.M.; Croft, T.; Tolman, J.; Vickers, J.; Stirling, C.; Robinson, A.; Turner, P. 2011. Hospital coding of Dementia: is it accurate? Health Information Management Journal, vol. 40, no. 3, pp. 5-11.

Dalal, S.; Roy, B. 2010. Reliability of Clinical Coding of Hip Facture Surgery: Implications for Payment by Results?", Inernational Journal Care Injured, vol. 40, no. 1 pp. 738-741.

Farzandipour, M.; Sheikhtaheri, A.; Sadoughi, F. 2010. Effective Factors on Accuracy of Principal Diagnosis Coding Based on International Classification of Diseases, the $10^{\text {th }}$ Revision (ICD-10), International Journal of Information Management, vol. 30, no. 5, pp. 78-84.

Hatta, G. 2013. Pedoman Manajemen Informasi Kesehatan di Sarana Pelayanan Kesehatan, Jakarta: Universitas Indonesia Press.

Iman, A.T. \& Barsasella, D. 2019. Pengaruh Kodifikasi ICD 10 dan ICD 9 CM terhadap Klaim JKN Rawat Inap di RSUD Dr. Soekardjo Kota Tasikmalaya Tahun 2018. JPHI. 6(22): 40-49.

Karimah, R.N.; Setiawan, D.; Nurmalia, P.S. 2016. Analisis Ketepatan Kode Diagnosis Penyakit Gastroenteritis Acute Berdasarkan
Dokumen Rekam Medis di Rumah Sakit Balung Jember, Journal of Agromedicine and Medical Sciences, vol. 2, no. 2, pp. 12-17.

Maryati, W. 2016. Faktor yang Mempengaruhi Kualitas Diagnosis Koding dan Rekam Medis di RSUD Dr. Moewardi Surakarta. Journal of Health Policy Management. 2 (1): 61-70

Maryati, W. 2017. Hubungan antara Keakuratan Kode Diagnosis Diabetes Mellitus dengan Ketepatan Klaim Asuransi, Seminar Manajemen Informasi Kesehatan, APIKES Citra Medika Surakarta, pp. 15-19.

Menteri Kesehatan RI.;, "Rekapitulasi Data Rumah Sakit", Diakses tanggal 15 Juli 2019 http://sirs.yankes.kemkes.go.id/rsonline/r eport/datars

Menteri Kesehatan RI.;. "Peraturan Menteri Kesehatan Republik Indonesia No. 76 Tahun 2016 Tentang Pedoman Indonesian Case Base Groups (INA-CBGs) dalam Pelaksanaan Jaminan Kesehatan Nasional", Jakarta, 2016.

Murti, B. 2015. Desain dan Ukuran Sampel untuk Penelitian Kuantitatif dan Kualitatif di Bidang Kesehatan. Yogyakarta: Gadjah Mada University Press.

Ningtyas, NK., Sugiarsi, S., Wariyanti, AS. 2019. Analisis Akurasi Kode Diagnosis Utama Kasus Persalinan Sebelum dan Sesudah Verifikasi pada Pasien BPJS di RSUP Dr. Soeradji Tirtonegoro Klaten. Jurnal Kesehatan Vokasional. 4(1):1-11.

Opitasari, C. \& Nurwahyuni, A. 2018. Kelengkapan dan Keakuratan Coding Klinis untuk Diagnosis dan Prosedur Medis Jumlah Klaim INA-CBGs di Rumah Sakit di Jakarta Selatan. HSJI. 9(1): 14-18.

Pujihastuti, A.; Sudra, R.I. 2014. Hubungan Kelengkapan Informasi dengan Keakuratan Kode Diagnosis dan Tindakan Pada Dokumen Rekam Medis Rawat Inap, Jurnal Manajemen Informasi Kesehatan Indonesia, vol. 3, no. 1 , pp. 60-64.

Rahayu, H.; Ernawati, D.; Kresnowati, L. 2011. Akurasi Kode Diagnosis Utama Pada RM 1 Dokumen Rekam Medis Ruang Karmel dan Karakteristik Petugas Koding Rawat Inap Rumah Sakit Mardi Rahayu Kudus Periode Desember 2009, Jurnal Visi Kesehatan, vol. 10, no. 1, pp. 1-5.

Rohman, H.; Hariyono, W.; Rosyidah. 2011. Kebijakan Pengisian Diagnosis Utama dan Keakuratan Kode Diagnosis Pada Rekam Medis di Rumah Sakit PKU Muhammadiyah Yogyakarta, Jurnal KESMAS, vol. 5, no. 2, pp. 162-232. 
Sarwastutik. 2013. Tinjauan Keakuratan Kode Diagnosis Pada Dokumen Rekam Medis Pasien Rawat Inap dengan Kondisi Utama Typhoid FeverBerdasarkan ICD-X di RSU PKU Muhammadiyah Delanggu, Jurnal Informasi Kesehatan, vol. 3, no. 2, pp. 8-13.

Seruni, F.D.A.; Sugiarsi, S. 2015. Problem Solving Cycle SWOT Keakuratan Kode Diagnosis Kasus Obstetri Pada Lembar Masuk dan Keluar (RM 1a) Pasien Rawat Inap di RSUD Dr. Sayidiman Magetan, Jurnal Manajemen Informasi Kesehatan Indonesia, vol. 3, no. 2, pp. 5-13.

Sudra, R.I.; Pujihastuti, A. 2016. Pengaruh Penulisan Dianosis dan Pengetahuan Petugas Rekam Medis tentang Terminologi Medis Terhadap Keakuratan Kode
Diagnosis", Jurnal Manajemen Informasi Kesehatan Indonesia, vol. 4, no. 1, pp. 67-72.

Thigpen, J.L.; Pharm; Dillon, C.; Forster, K.B.; Henault, L.; Quinn, E.K.; Tripodis, Y.; Berger, P.B.; Hylek, E.M.; Limdi, N.A. 2015. Validity of International Classification of Disease Codes to Identify Ischemic Stroke and Intracranial Hemorrhage among Individuals with Associated Diagnosis of Atrial Fibrillation. Circulatory Cardiovascular Quaility Outcomes, vol. 8, no. 1, pp. 8-14.

Widyaningrum, L. 2015. Akurasi diagnosis dan pemilihan ulang kode utama berdasarkan Aturan Morbiditas Asuransi Kesehatan INA-CBGs. JMIKI. 3(2): 27-31.

World Health Organization, 2010. International Satistical Classification of Diseases and Related Health Problems Tenth Revision volume 1, 2 dan 3, Geneva. 